\title{
Identification and field evaluation of the sex pheromone of a Brazilian population of Spodoptera cosmioides
}

\author{
Maria Carolina Blassioli-Moraes(1), Miguel Borges ${ }^{(1)}$, Amanda Rodrigues Viana(1), Raúl Alberto Laumann ${ }^{(1)}$, \\ José Ednilson Miranda( ${ }^{(2)}$, Diego Martins Magalhães ${ }^{(3)}$ and Michael A. Birkett(4)
}

\begin{abstract}
(1)Embrapa Recursos Genéticos e Biotecnologia, Parque Estação Biológica, W5 Norte (Final), Caixa Postal 02372, CEP 70770-917 Brasília, DF, Brazil. E-mail: carolina.blassioli@embrapa.br, miguel.borges@embrapa.br, amanda_2111@hotmail.com, raul.laumann@embrapa.br (2)Embrapa Algodão, Rodovia GO-462, Km 12, Zona Rural, CEP 73375-000 Santo Antônio de Goiás, GO, Brazil. E-mail: jose-ednilson.miranda@embrapa.br (3)Universidade de Brasília, Instituto de Ciências Biológicas, Campus Universitário Darcy Ribeiro, CEP 70910-900 Brasília, DF, Brazil. E-mail: magalhaes.dmm@gmail.com ${ }^{(4)}$ Biological Chemistry and Crop Protection Department, Rothamsted Research, AL5-2JQ Harpenden, United Kingdom. E-mail: mike.birkett@rothamsted.ac.uk
\end{abstract}

\begin{abstract}
The objective of this work was to identify the sex pheromone of Spodoptera cosmioides and to evaluate whether there is pheromone cross-attraction in Spodoptera sp. (Lepidoptera: Noctuidae). Spodoptera cosmioides gland extracts were analyzed by GC-FID and GC-MS. Wind tunnel and electrophysiology experiments were conducted to evaluate the role of gland compounds. In the field, different pheromone traps were tested: $S$. frugiperda commercial lure; (9Z)-9-tetradecenyl acetate (Z9-14:OAc) and (9Z,12E)-9,12-tetradecadienyl acetate (Z9,E12-14:OAc) trap; two females of $S$. cosmioides trap; and hexane control trap. Four acetates were identified in the $S$. cosmioides female gland extracts as Z9-14:OAc, Z9,E12-14:OAc, (11Z)-11-hexadecenyl acetate (Z11-16:OAc) and hexadecyl acetate (16:OAc), but only the first two acetates induced electrophysiological responses from $S$. cosmioides male antennae. In wind tunnel experiments, $S$. cosmioides and $S$. frugiperda males responded more strongly to conspecific blends; however, there was some cross-attraction, as $47 \%$ males of $S$. frugiperda and $25 \%$ males of $S$. cosmioides responded to heterospecific blends. In field experiments, $S$. frugiperda and $S$. cosmioides showed the same response pattern as observed in the wind tunnel bioassays. In summary, the sex pheromone components of $S$. cosmioides are Z9-14:OAc and $Z 9, E 12-14 \mathrm{OAc}$; they are important for conferring species specificity, and there is pheromone-mediated cross attraction between $S$. frugiperd $a$ and $S$. cosmioides.
\end{abstract}

Index terms: (9Z)-9-tetradecenyl acetate, $(9 Z, 12 E)$-9,12-tetradecadienyl acetate, cross-attraction, electrophysiology, pest monitoring, pheromone traps.

\section{Identificação e avaliação em campo do feromônio sexual de uma população brasileira de Spodoptera cosmioides}

Resumo - O objetivo deste trabalho foi identificar o feromônio sexual de Spodoptera cosmioides e avaliar se existe atração cruzada em Spodoptera sp. (Lepidoptera: Noctuidae). Extratos de glândulas de S. cosmioides foram analisados por GC-FID e GC-MS. A ação dos compostos encontrados nas glândulas foi avaliada por meio de bioensaios em túnel de vento e eletrofisiologia. Em campo, testaram-se diferentes armadilhas feromonais: com feromônio comercial de $S$. frugiperda; com acetato de (9Z)-9-tetradecenila (Z9-14:OAc) e acetato de (9Z,12E)-9,12-tetradecadienila (Z9,E12-14:OAc); com duas fêmeas de S. cosmioides; e controle com hexano. Quatro acetatos foram identificados nas glândulas de fêmeas de $S$. cosmioides como Z9-14:OAc, Z9,E12-14:OAc, (11Z)-acetato de hexadecenila e acetato de hexadecila (16:OAc), mas somente os dois primeiros acetatos induziram resposta eletrofisiológica nas antenas de machos de $S$. cosmioides. Nos bioensaios em túnel de vento, machos de $S$. cosmioides e $S$. frugiperda responderam em maior número à mistura de coespecíficos; no entanto, houve atração cruzada, uma vez que $47 \%$ dos machos de $S$. frugiperda e $25 \%$ dos machos de $S$. cosmioides responderam à mistura heteroespecífica. Nos experimentos em campo, $S$. frugiperda e $S$. cosmioides mostraram o mesmo padrão de resposta observado nos bioensaios em túnel de vento. Em resumo, os componentes do feromônio sexual de S. cosmioides são Z9-14:OAc e Z9,E12-14:OAc, que são importantes para conferir espécie-especificidade do feromônio, e há atração cruzada entre $S$. cosmioides e S. frugiperda mediada por feromônios.

Termos para indexação: acetato de (9Z)-9-tetradecenila, acetato de (9Z,12E)-9,12-tetradecadienila, atração cruzada, eletrofisiologia, monitoramento de pragas, armadilhas feromonais.

\section{Introduction}

The black armyworm, Spodoptera cosmioides Walker (Lepidoptera: Noctuidae), is a moth that occurs in tropical South America (Silvain \& Lalanne-Cassou, 1997). In Brazil, it has been registered on more than 30 different crops, including soybean, maize, cotton, coffee, onion, and sunflower, causing severe 
damage that leads to substantial losses of production (Nagoshi, 2009; Lima et al., 2015). Due to its economic importance, several studies on the biology, rearing methods, biological control, and economic damage have been conducted for the population of S. cosmioides in Brazil (Bavaresco et al., 2004; Pomari et al., 2013).

Spodoptera cosmioides was considered a synonym for Spodoptera latifascia Walker(Lepidoptera: Noctuidae), but previous studies of French Guiana populations showed important differences in morphology, physiology, and sex pheromone composition (Silvain \& Lalane-Cassou, 1997; Lalanne-Cassou et al., 1999). The sex pheromone for French Guiana populations was identified as a blend, consisting of two components, (9Z)-9-tetradecenyl acetate (Z9-14:OAc) and $(9 Z, 12 E)-9,12$-tetradecadienyl acetate $(Z 9, E 12-$ 14:OAc) (Teixeira et al., 1989; Monti et al., 1995; Lalanne-Cassou et al., 1999). Studies have shown that there is great variability in the sex pheromone composition in Lepidoptera of different populations, even for strains that share the same habitat (El-Sayed et al., 2003). For instance, corn and rice strains of S. frugiperda (J.E. Smith) (Lepidoptera:Noctuidae) that inhabit the same geographic area have different calling time and sex pheromone blends (Groot et al., 2008; Unbehend et al., 2013). If this phenomenon is extended to other species of Spodoptera, there is a possibility that the population of $S$. cosmioides from French Guiana emits a different sex pheromone blend compared to the populations from central Brazil.

The use of sex pheromones combined with other control measures, such as biological control, could be an important strategy to manage Spodoptera spp. in Brazil, and to minimize the large amount of insecticides currently used to control Spodoptera populations in crop fields (Moscardi et al., 2012). The sex pheromones of $S$. eridania (Cramer), $S$. exigua (Hubner), S. frugiperda, and S. praefica (Grote) are commercially available (Meagher et al., 2008). The identification of $S$. cosmioides sex pheromone composition could be a relevant tool for its management. In addition, it is well known that some insect pheromones, when tested in field conditions, show cross-attraction to related species; this phenomenon has been reported for Hemiptera (Endo et al., 2006; Tillman et al., 2010), Coleoptera and Lepidoptera, including some species of Spodoptera (Mitchell \& Tumlison, 1994; Meagher et al., 2008). In many regions of Brazil, populations of $S$. cosmioides are found coexisting with populations of S. frugiperda and S. eridania (Teodoro et al., 2013), thus, the possibility for identifying an attractive pheromone blend for different species could help to develop a multitarget monitoring technique.

The objective of this work was to identify the sex pheromone blend of $S$. cosmioides from Brazil, and to evaluate whether there was cross-attraction with S. frugiperda.

\section{Materials and Methods}

Spodoptera cosmioides larvae and pupae were obtained from a laboratory colony maintained at Embrapa Arroz e Feijão in Santo Antônio de Goiás, $\mathrm{GO}$, Brazil (16 $\left.4^{\circ} \mathrm{S}, 49^{\circ} 14^{\prime} \mathrm{W}\right)$, and S. frugiperda pupae were obtained from a laboratory colony maintained at Embrapa Recursos Genéticos e Biotecnologia in Brasília, DF, Brazil (154 $\left.7^{\prime} \mathrm{S}, 4^{\circ} 55^{\prime} \mathrm{W}\right)$.

Pupae were sexed and placed inside $3 \mathrm{~L}$ plastic containers. After emergence, male and female moths were kept separately. Adults were fed with a sugar solution comprising $1 \mathrm{~L}$ water, $50 \mathrm{~g}$ honey, $50 \mathrm{~g}$ sugar, $1 \mathrm{mg}$ Nipagin, and $1 \mathrm{mg}$ ascorbic acid (Schmidt et al., 2001). For bioassays, all insects were 1 to 3-days-old. The insects were reared in climate chambers (Lab-Line, Mellrose Park, Ill, USA) on a 12:12 light: dark reverse photoperiod at $25^{\circ} \mathrm{C}$ and $65 \%$ relative humidity.

Sex pheromone glands were excised from 2-4-day-old virgin calling females. Glands were forced to extrusion by gently pressuring the tip of the abdomen and were excised using small spring scissors model 15003-08 (FST, Vancouver, CO, Canada). Five to eight glands were placed in a $0.5 \mathrm{~mL}$ conical vial containing $100 \mu \mathrm{L}$ of hexane, and were extracted at room temperature for $20 \mathrm{~min}$. The extracts were filtered, using glass wool to remove solid particles, and pre-concentrated to $50 \mu \mathrm{L}$ under a pure $\mathrm{N}_{2}$ flow. The extracts $(\mathrm{N}=6)$ were stored at $-20^{\circ} \mathrm{C}$ until use.

The gland extracts were analysed by GC (Agilent 7890A, DB-5MS column, $60 \mathrm{~m} \times 0.32 \mathrm{~mm}$ ID, 0.25 $\mu \mathrm{m}$ film, Supelco, Bellefonte, PA, USA), with the oven temperature maintained at $50^{\circ} \mathrm{C}$ for $2 \mathrm{~min}$, then increased at $5^{\circ} \mathrm{C} \mathrm{min}{ }^{-1}$ to $180^{\circ} \mathrm{C}$ for $0.1 \mathrm{~min}$, followed by a gradual increase of $10^{\circ} \mathrm{C} \mathrm{min}^{-1}$ to $250^{\circ} \mathrm{C}$ for $20 \mathrm{~min}$. The column effluent was analysed with a flame ionization detector (FID) at $270^{\circ} \mathrm{C}$. One microliter of each sample was injected in splitless mode with 
helium as carrier gas. The samples were also analysed using a DB-WAX column and subjected to the same temperature program and flow conditions, to calculate the retention index (RI) of each compound. The data were collected with EZChrom Elite software and handled using Excel (Microsoft Office 2007, Microsoft Corporation, USA). For compound identification, selected extracts were analysed using an Agilent 5975C quadrupole mass spectrometer equipped with a DB-5MS (30 x $0.25 \mathrm{~mm}$ ID, $0.25 \mu \mathrm{m}$ film, Supelco, Bellefonte, PA, USA), DB-WAX column (30 x $0.25 \mathrm{~mm}$ ID, $0.25 \mu \mathrm{m}$ film, Supelco, Bellefonte, PA, USA) and a splitless injector, with helium as carrier gas. Ionization was achieved by electron impact $\left(70 \mathrm{eV}\right.$, source temperature $200^{\circ} \mathrm{C}$ ), and the data were collected with ChemStation software. Identifications were made by comparison of spectra with library databases (National Institute of Standards and Technology, 2008), or with published spectra, using retention indices (published at Pherobase and NIST Chemistry Web Book web sites), and confirmed by GC co-injection using authentic standards.

Gas chromatography - electroantennographic detection (GC-EAD) was used to determine compounds within mixtures that were detected by the male antennae. For this purpose, a Perkin Elmer Autosystem XL GC (NY, USA) was coupled to an EAD detector (Syntech, Inc., Hilversum, The Netherlands). The GC was equipped with a nonpolar DB-5 column (30 m x $0.25 \mathrm{~mm}$ ID, $0.25 \mu \mathrm{m}$ film, J\&W Scientific, Folsom, CA, USA), and a splitless injector with helium as the carrier gas. The oven temperature was programmed to start at $50^{\circ} \mathrm{C}(2 \mathrm{~min})$, then rise to $250^{\circ} \mathrm{C}$ at $15^{\circ} \mathrm{C} \mathrm{min}{ }^{-1}$ and hold at this temperature for $10 \mathrm{~min}$. The effluent temperature to the GC-EAD system was kept at $195^{\circ} \mathrm{C}$. The antennae of one male were removed by using a small spring scissors and were immediately placed in stainless steel electrodes. The electric connection was achieved using conductive gel. The electrodes were connected to an autospike interface box and an AC/DC amplifier IDAC-2 (Syntech, Inc., The Netherlands). Preparations were done in a continuous humidified air flow $\left(1 \mathrm{~L} \mathrm{~min}^{-1}\right)$ with a Stimulus Controller CS-55 (Syntech, Inc., Hilversum, The Netherlands). Antennae of $S$. cosmioides males were tested using conspecific females gland extracts $(\mathrm{N}=5)$. Only peaks that showed depolarization and the repolarization of the antennae were considered as GC-EAD responses, and only those compounds that elicited responses in all tested antennae $(\mathrm{N}=5)$ were considered electrophysiologically active. A single antennal preparation was used for only one chromatography analysis.

The synthesis of Z7-12:OAc and Z9-14:OAc was carried out following published procedures using aleuritic acid (Ujváry et al., 1985). Proton nuclear magnetic resonance ( ${ }^{1} \mathrm{H}$ NMR) spectroscopy was performed using a Bruker Avance $500 \mathrm{MHz}$ NMR spectrometer (Coventry, West Midlands, UK) equipped with a $2.5 \mathrm{~mm}$ microprobe. Chemical shifts (in parts per million) from the ${ }^{1} \mathrm{H}$ NMR data were compared with literature values (Ujváry et al., 1985). The synthesis provided $655 \mathrm{mg}$ (26.3\% yield) of Z7-12:OAc: (98\% $Z$ purity) ${ }^{1} \mathrm{H}$ NMR $\left(500 \mathrm{MHZ}, \mathrm{CDCl}_{3}\right) \delta 0.96$ (t, $3 \mathrm{H}, J$ 7.0, $\left.\mathrm{CH}_{3}\right), 1.96\left(\mathrm{~m}, 4 \mathrm{H}, \mathrm{CH}_{2}\right), 1.3-1.69(\mathrm{~s}+\mathrm{m}, 10 \mathrm{H}$, $\left.\mathrm{CH}_{2}\right), 2.25\left(\mathrm{~m}, 2 \mathrm{H}, \mathrm{CH}_{2}\right), 4.01\left(\mathrm{t}, 3 \mathrm{H}, J 6.0, \mathrm{OCH}_{3}\right), 5.32$ $(\mathrm{m}, 2 \mathrm{H}, J 10.5, \mathrm{CH}=\mathrm{CH}) . \mathrm{MS}: \mathrm{m} / z=166(20), 138(6)$, 124(7), 123(11), 110(26), 109(32), 96(61), 95(55), 82(83), 81(94), 69(33), 68(48), 67(100), 55(78), $54(50)$ and $522 \mathrm{mg}$ (43.76\% yield) of Z9-14:OAc (96\% $Z$ isomer purity): ${ }^{1} \mathrm{H}$ NMR (500 $\mathrm{MHZ}, \mathrm{CDCl}_{3}$ ) $\delta 0.96\left(3 \mathrm{H}, \mathrm{t}, J=7 \mathrm{~Hz}, \mathrm{CH}_{3}\right), 1.96\left(4 \mathrm{H}, \mathrm{m}, \mathrm{CH}_{2}\right), 1.33$ $-1.68\left(10 \mathrm{H}, \mathrm{s}+\mathrm{m}, \mathrm{CH}_{2}\right), 2.25\left(2 \mathrm{H}, \mathrm{m}, \mathrm{CH}_{2}\right), 3.99(3 \mathrm{H}$, $\left.\mathrm{t}, J=6.5 \mathrm{~Hz}, \mathrm{OCH}_{3}\right), 5.42(2 \mathrm{H}, \mathrm{m}, J=12.5, \mathrm{CH}=\mathrm{CH})$ MS: $m / z=194(21), 138(8), 137(8), 124(14), 123(14)$, 110(34), 109(30), 96(79), 95(61), 82(100), 81(92), 69(41), 68(47), 67(81), 55(95), 54(45).

Behavioural bioassays were conducted in a $1.5 \times 0.5$ $\mathrm{x} 0.5 \mathrm{~m}(\mathrm{LxWxH})$ wind tunnel. Bioassays with $S$. cosmioides and $S$. frugiperda were conducted using $0.5 \mathrm{~m} \mathrm{~s}^{-1}$ airflow. Treatments were spotted on filter paper strips (1.5 cm long and $0.5 \mathrm{~cm}$ wide) (Whatman no. 1), which were placed inside a metal mesh cage. The cage was placed on a support $15 \mathrm{~cm}$ above the wind tunnel floor and $30 \mathrm{~cm}$ from the upwind end of the tunnel. Males were released individually and, before testing, were allowed to acclimate for $5 \mathrm{~min}$ inside the wind tunnel while assembling the treatment cages. Male behavioural monitored steps were: taking flight, moving antennae, exposing the genitalia, and landing on the odour source. The first set of bioassays evaluated $S$. cosmioides and $S$. frugiperda male responses towards conspecific calling females, using the procedure described above, but with five calling females as the odour source.

In the second set of bioassays, $S$. cosmioides and $S$. frugiperda males were tested against five 
heterospecific females as the odour source, to verify whether they were attracted to the pheromone from other species. The third set of bioassays was done to verify whether all identified compounds in $S$. cosmioides female glands play a role as sex pheromone components. The attraction of $S$. cosmioides males was evaluated for the following treatments: Z9-14:OAc and $Z 9, E 12-14: O A c$ tested individually at two different amounts $(2.5$ and $5 \mu \mathrm{g})$; Mix-1, Z9-14:OAc $+Z 9, E 12-14$ :OAc (2.5:0.25 $\mu \mathrm{g})$; Mix-2, Z9-14:OAc + Z9,E12-14:OAc (0.25:0.025 $\mu \mathrm{g})$; Mix-3, Z9-14:OAc + Z9,E12-14:OAc (0.025:0.0025 $\mu \mathrm{g})$; Mix-4, Z9-14:OAc $+Z 9, E 12-14: O A c+Z 11-16: O A c(0.5: 0.025: 0.025 \mu \mathrm{g})$; and Mix-5, Z9-14:OAc + Z9,E12-14:OAc + Z11-16:OAc + 16:OAc (3.6:0.6:0.6:0.03 $\mu \mathrm{g})$, using a similar ratio that was quantified from the gland extracts.

The fourth set of bioassays verified the possibility of cross-attraction between Spodoptera spp. Therefore, cross-attraction was evaluated for $S$. frugiperda males to Mix-1, which attracted $S$. cosmioides males, and contained one compound that is not present in the sex pheromone blend of Brazilian populations of $S$. frugiperda and Mix-6 containing Z9-14:OAc + Z9,E12-14:OAc + Z7-12:OAc (5:0.5:0.02 $\mu \mathrm{g})$ was evaluated for both species. The ratio between the components was determined from previous experiments conducted in our laboratory.

All bioassays were conducted in a dark room, using a red light (14 Watts, Twister, Taschibra Indaial-SC, Brazil), at $27^{\circ} \mathrm{C}$ and $65 \%$ relative humidity. For each treatment, 30 replicates were carried out and males were used only once. All bioassays were recorded from 5 to 9 hours within scotophase (Lalanne-Cassou et al., 1999). For the statistical analysis, only males that were capable of flying were ranked for: males that flew up wind but did not land on the odour source; and males that flew up wind and landed on the odour source. Each observation lasted $5 \mathrm{~min}$, after which males were removed.

Field trials were conducted in Santa Helena de Goiás, $\mathrm{GO}$, Brazil $\left(17^{\circ} 48^{\prime} \mathrm{S}, 50^{\circ} 35^{\prime} \mathrm{W}\right)$ during April 2012. Four different treatments $(\mathrm{N}=5$ for each treatment) were settled: A, grey rubber septa $(11 \mathrm{~mm})$ impregnated with $1 \mathrm{mg}$ pentane, which was called Blank; B, two-day-old $S$. cosmioides females; C, Biofrugiperda, a commercial pheromone of $S$. frugiperda (Biocontrole, São Paulo, SP, Brazil), which contained three compounds
Z9-12:OAc, Z11-16:OAc and Z7-12:OAc; and D, grey rubber septa impregnated with $1 \mathrm{mg}$ of $Z 9-14$ :OAc and $Z 9, E 12-14: O A c$ in the ratio $(10: 1)$. The experiment was performed in a cotton field at vegetative stage. Each treatment was hung up inside Delta traps (AR905-Plastic Delta traps - Isca Technologia, Ijuí, RS, Brazil), which were distributed in a completely randomized design and spaced $50 \mathrm{~m}$ from each other in a $5 \times 4$ grid. The traps were examined every three days when insects were identified and quantified, and virgin females of treatment B were replaced. After each monitoring period, the sticky floor of the traps was replaced and traps were reallocated to avoid positional bias. The total duration of the experiments was three weeks.

Statistical analysis was performed with R 3.0.1 (R Development Core Team, 2007). Data from wind tunnel bioassays were analysed using a GLM with a binomial distribution. The proportion and confidence interval (95\%) of responding insects to each treatment were also calculated. In the field experiments, the total number of males of each species ( $S$. frugiperda and $S$. cosmioides) captured in the traps, during all the experimental period, were used to compare the effect of treatment. The analyses were performed using a GLM with Poisson distribution of errors and the deviance analysis with 95\% confidence level, using the number of insect per trap as a dependent variable, and treatment as the fixed effect. The mean number of insects captured by treatment was compared by contrast analysis.

\section{Results and Discussion}

Chemical analysis of gland extracts from $S$. cosmioides females showed the presence of four compounds that are typical for noctuid moth sex pheromones: (9Z)-9-tetradecenyl acetate, $\quad(9 Z, 12 E)-9,12$-tetradecadienyl acetate, (11Z)-11-hexadecenyl acetate and hexadecyl acetate (Figure 1). These compounds are also found in several other species from different families (Ando et al., 2004; Acín et al., 2010; Ma et al., 2014). In addition, five other compounds were tentatively identified as methyl tetradecanoate, octadecane, hexadecan-1-ol, heptadecan-1-ol and docosane. The latter five compounds may be by-products of pheromone biosynthesis (Jurenka, 2004), since there was no 
response of male antennae to these compounds. In coupled GC-electroantennography, S. cosmioides male antennae responded only to Z9-14:OAc and Z9,E12-14:OAc from the gland extracts of $S$. cosmioides females (Figure 2). The antennae did not show a clear response to the other acetates present in female gland extracts. The biosynthetic route of the pheromone components in moths shows that 16:OAc and Z11-16:OAc are the precursors of Z9-14:OAc, $Z 7-12: O A c$ and Z9,E12-14:OAc (Jurenka, 2004; Groot et al., 2008; Saveer et al., 2014), therefore, these compounds are not directly involved in male attraction. Batista-Pereira et al. (2006) reported that Z11-16:OAc did not increase male attraction to a synthetic blend of $S$. frugiperda pheromone containing Z7-12:OAc and Z9-14:OAc. The retention index obtained from polar and nonpolar columns (Table 1), and the fragmentation pattern from coupled GC-MS analysis of the four typical Noctuidae compounds identified from the gland extracts matched with the following compounds: Z9-14:OAc $(\mathrm{m} / \mathrm{z}$ 194, 109, 96, 95, 82, 81, 67, 61, 55, 53, 43, 41), Z9,E12-14:OAc ( $\mathrm{m} / \mathrm{z} 192,163,149,135$, $121,107,95,93,81,79,68,67,55), Z 11-16:$ OAc $(\mathrm{m} / \mathrm{z}$

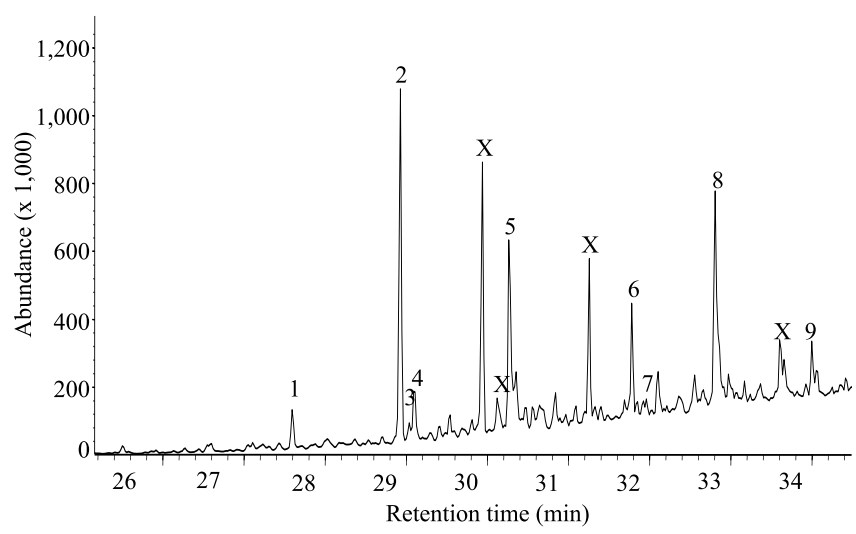

Figure 1. GC-MS chromatogram profile obtained from an extract containing eight glands from females of Spodoptera cosmioides. 1, Methyl tetradecanoate (RI = 1724); 2, (9Z)-9-tetradecenyl acetate (Z9-14:OAc), 3, octadecane $(\mathrm{RI}=1800) ; 4,(9 Z, 12 E)-9,12$-tetradecadienyl acetate (Z9,E12-14:OAc); 5, hexadecan-1-ol* (RI = 1881); 6, (11Z)-11-hexadecenyl acetate (Z11-16OAc); 7, hexadecyl acetate (16:OAc); 8, heptadecan-1-ol* (RI- 1982); 9, docosane (2000). *These compounds were identified by RI, comparing the fragmentation pattern of the mass spectra with data from the National Institute of Standards and Technology (NIST) and Wiley library. X, Phthalate derivatives.
$222,152,137,124,110,96,95,82,81,68,67,61$, 55) and 16:OAc $(\mathrm{m} / \mathrm{z} 224,154,140,125,111,97$, $83,69,55)$. The co-elution of the synthetic sample together with natural components confirmed the tentative identification (Figure 3). The ratio between the components and the amount of each compound varied between individuals (Table 1). Using the major compound as the reference, the ratio obtained between the components was 10:1.8:1.9:0.08.

In wind tunnel bioassays, conspecific $S$. cosmioides calling females used as the odour source stimulated $100 \%$ S. cosmioides males to display reproductive behaviour, which consisted of antennation, genital exposure and zigzag flights. Furthermore, $56 \%$ of these males landed on the odour source (Figure 4 A). Similarly, $S$. frugiperda males responded to calling conspecific females; $100 \%$ of these males showed

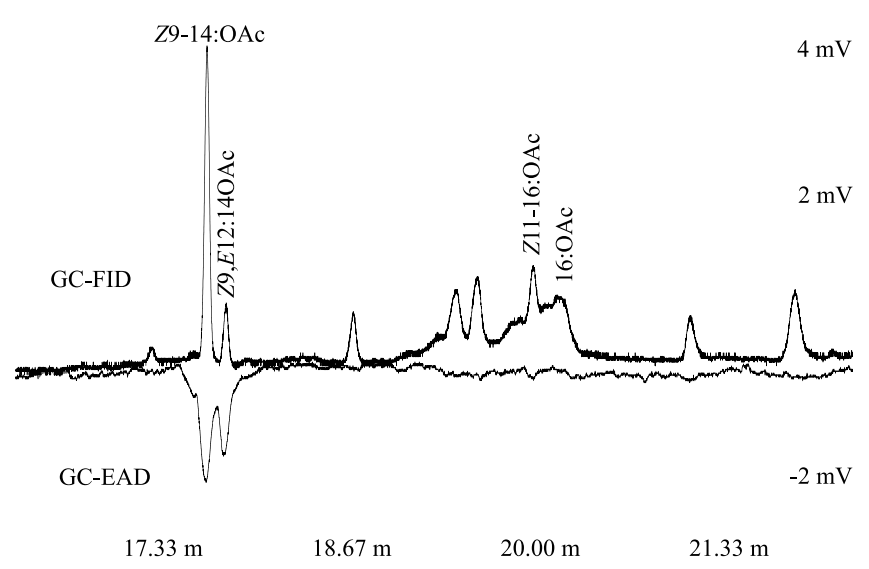

Figure 2. Typical response of Spodoptera cosmioides male antennae to female gland extracts (containing eight glands), in a coupled gas chromatography-electroantennography detection (GC-EAD) experiment.

Table 1. Compounds identified in female gland extracts of Spodoptera cosmioides, the retention index (RI), and the produced amount of each compound \pm standard error (SE) per gland, $\mathrm{n}=6$.

\begin{tabular}{lccc}
\hline Compound & RI & RI & Amount per \\
& DB-5MS & DB-WAX & gland (ng) \\
\hline (9Z)-9-Tetradecenyl acetate & 1795 & 2144 & $63.54 \pm 16.34$ \\
(9Z,12E)-9,12-Tetradecadienyl acetate & 1805 & 2233 & $11.71 \pm 3.09$ \\
(11Z)-11-Hexadecenyl acetate & 2002 & 2326 & $12.54 \pm 2.02$ \\
Hexadecyl acetate & 2008 & 2292 & $0.51 \pm 0.14$ \\
\hline
\end{tabular}

The RI was calculated using a DB-5-MS and DB-Wax column. 
reproductive behaviour, and $66 \%$ of them landed on the odour source. When $S$. cosmioides males were stimulated with five calling $S$. frugiperda females, only $25 \%$ of males landed on the odour source, whereas $65 \%$ S. frugiperda males landed on the odour platform when five $S$. cosmioides females were used as odour source (Figure $4 \mathrm{~B}$ ). The results suggest that the sex pheromone blend produced by $S$. frugiperda is more species-specific compared to that of $S$. cosmioides, considering the cross-attraction between these two species. Spodoptera frugiperda males response to $S$. cosmioides females might be related to the production of specific and shared components.

The major compound of $S$. frugiperda is Z9-14:OAc, comprising up to $83 \%$ of the total blend, and the second most abundant component is Z11-16:OAc (Groot et al., 2008; Batista-Pereira et al., 2006). These two compounds are also the two major compounds identified in the $S$. cosmioides female glands (Table 1). The main differences between both species is the presence of the minor component Z7-12OAc in the gland of $S$. frugiperda (1.5\% of the total blend) (Groot et al., 2008), and the compound Z9,E12-14:OAc in the gland of $S$. cosmioides, which is present at approximately $11 \%$ of the total blend. Although the literature reports that blends without Z7-12:OAc did not attract $S$. frugiperda males, the laboratory bioassays conducted in the present work showed attraction. Reports on Z7-12:OAc as a crucial component for male attraction were conducted with populations that produce a different sex pheromone blend, in comparison to $S$. frugiperda Brazilian population (Batista-Pereira et al., 2006; Groot et al., 2008). The response of $S$. frugiperda males to $S$. cosmioides females can be explained if $Z 7-12$ :OAc is an important component but not crucial for short-distance attraction, as in the wind tunnel bioassays, and if $S$. frugiperda males use other cues to locate females, such as visual or sound stimuli, in addition to chemical cues. Further studies are necessary to verify this hypothesis.
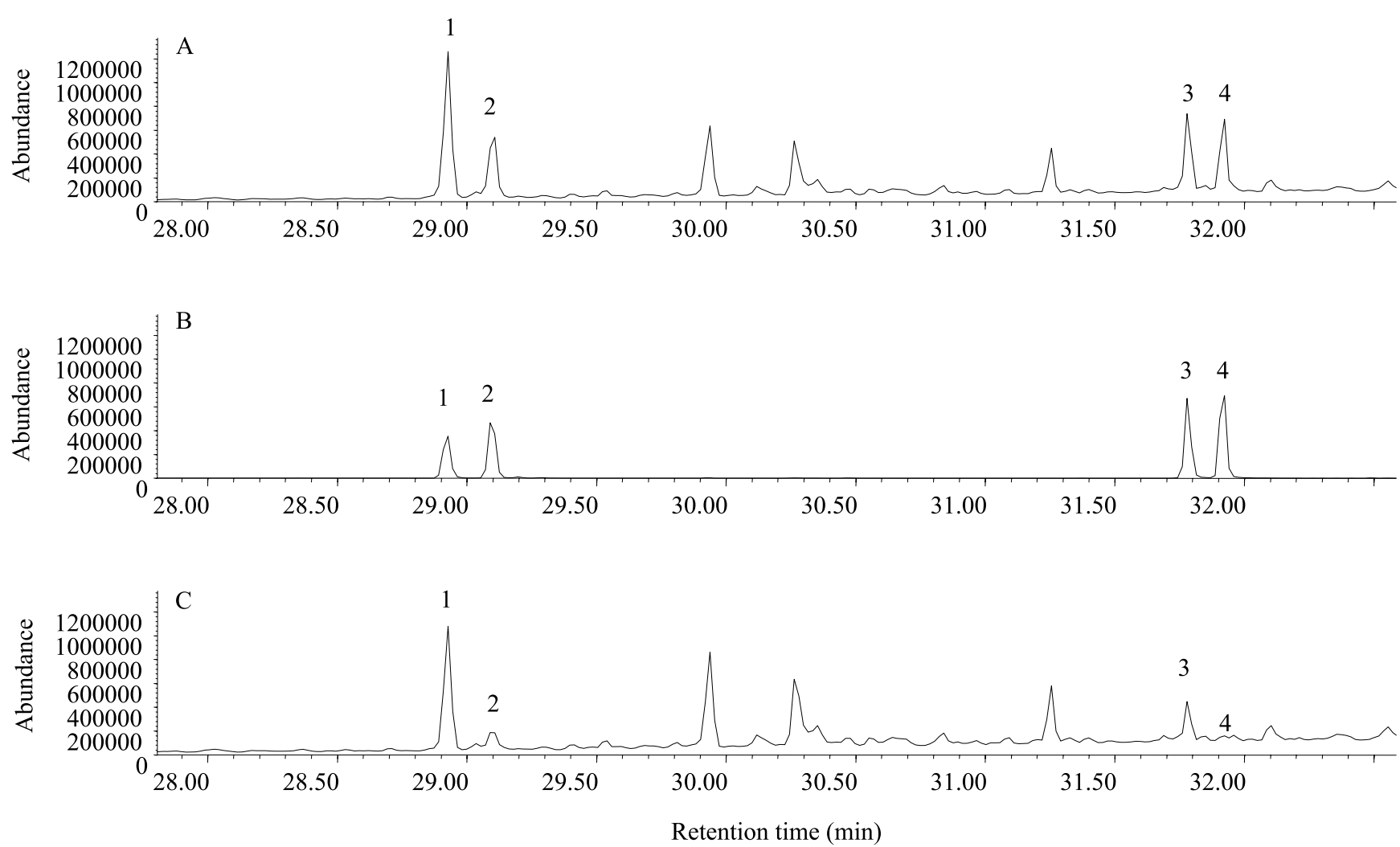

Figure 3. Co-injection of: A, synthetic solution containing the four components Z9-14:OAc, Z9,E12-14:OAc, Z11-16:OAc, and 16:OAc of Spodoptera cosmioides female gland extracts; B, chromatographic profile of the synthetic solution containing the four components (Z9-14:OAc, Z9,E12-14:OAc, Z11-16:OAc, and 16:OAc); and C, chromatographic profile of the female gland extracts. 
Wind tunnel bioassays with $S$. cosmioides males using synthetic compounds showed that Z9-14:OAc and Z9,E12-14:OAc, when evaluated individually, induced the attraction of males to the odour source, but in lower proportion compared to the conspecific female treatment. When the binary treatment Mix-1 containing Z9-14:OAc and Z9,E12-14:OAc (5:0.5 $\mu \mathrm{g})$ was tested, $56 \%$ of males landed on the odour source. A second binary treatment Mix-2 containing the same ratio of these two components [but in a lower amount $(0.25: 0.025 \mu \mathrm{g})]$ elicited $60 \%$ of males to land on the odour source. However, a third binary treatment
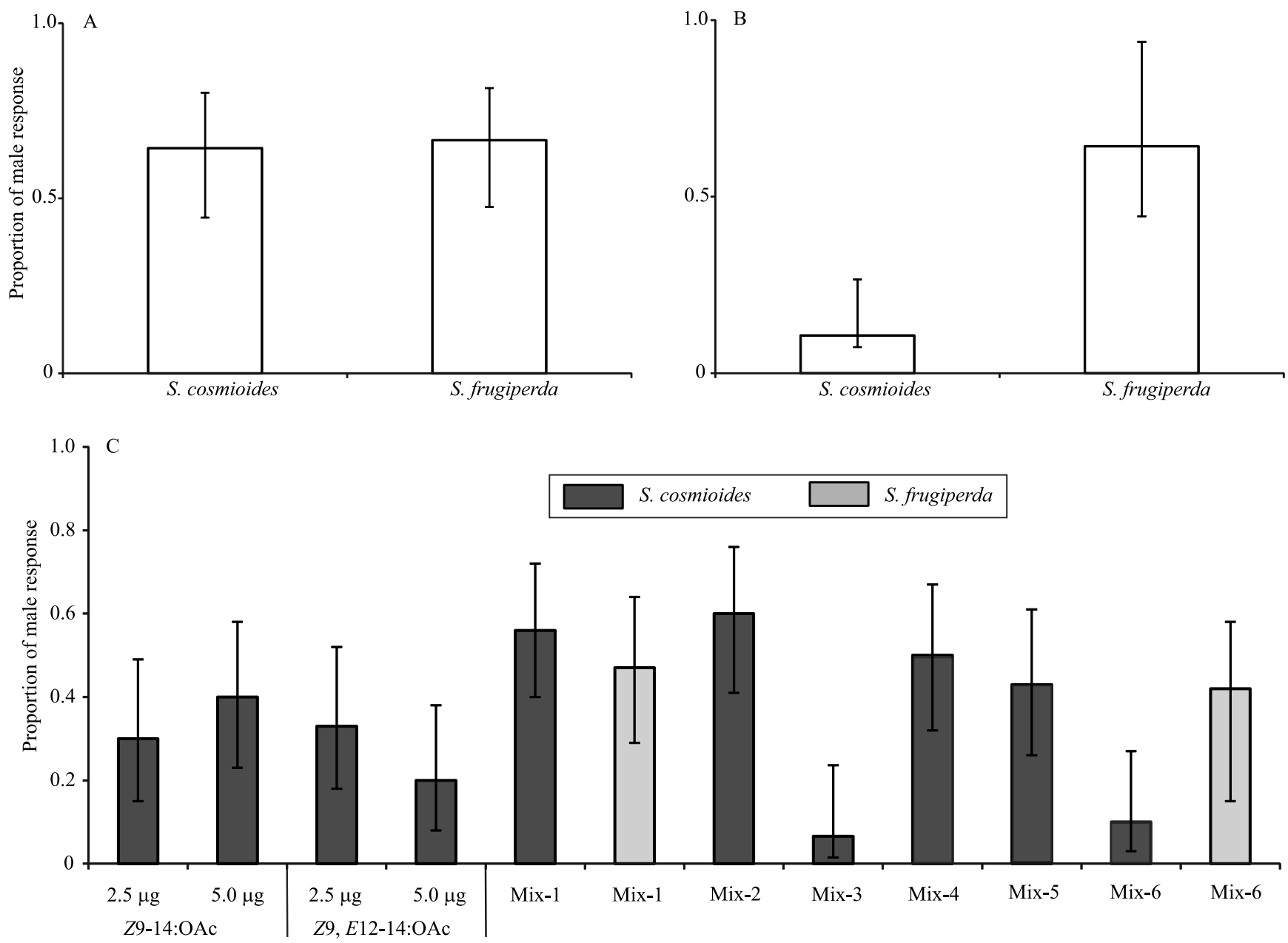

Figure 4. Responses of male Spodoptera cosmioides and S. frugiperda in wind tunnel bioassays to: A, five calling conspecific females; B, five calling heterospecific females; C, proportion \pm confidence interval of $S$. cosmioides and $S$. frugiperda male responses to synthetic solutions in the wind tunnel bioassays. Individual compounds: $2.5 \mu \mathrm{g}$ and $5.0 \mu \mathrm{g}$ of (Z9-14:OAc); $2.5 \mu \mathrm{g}$ and $5.0 \mu \mathrm{g}$ of (Z9,E12-14:OAc); Mix-1, (Z9-14:OAc + Z9,E12-14:OAc), 2.5:0.25 $\mu \mathrm{g}$; Mix-2, (Z9-14:OAc + Z9,E12-14:OAc),

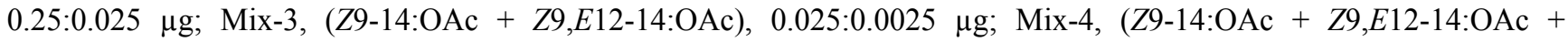
Z11-16:OAc), 0.5:0.025:0.025 $\mu \mathrm{g}$; Mix-5, (Z9-14:OAc + Z9,E12-14:OAc + Z11-16:OAc + 16:OAc), 3.6:0.6:0.8:0.03 $\mu \mathrm{g}$; and Mix-6, $(Z 9-14: \mathrm{OAc}+Z 9, E 12-14: \mathrm{OAc}+Z 7-12: \mathrm{OAc})$, 5:0.5:0.02 $\mu \mathrm{g}$. 
are precursors of the main components of the sex pheromone of Spodoptera sp. and they neither elicited any response from males, nor showed an antagonist effect. By contrast, when Z7-12:OAc was added to the binary blend (Mix-6), only $10 \%$ of $S$. cosmioides males landed on the odour source, showing that this component is important for the reproductive isolation of both species. When Mix-6 was tested with $S$. frugiperda males only $47 \%$ of individuals landed on the odour platform. The presence of Z9,E12-14:OAc decreased the attraction of $S$. frugiperda in comparison to the percentage of individuals that landed when conspecific females were used as odour source. The same percentage of $S$. frugiperda males landed on the odour source, when the binary blend containing Z9-14:OAc and Z9,E12-14:OAc was evaluated. This shows that the presence of Z7-12:OAc did not increase the attraction; however, the presence of Z9,E12-14:OAc inhibited the attraction of some individuals. The results obtained in the bioassays indicate that both specific compounds Z7-12:OAc (S. frugiperda) and Z9E12:14OAc (S. cosmioides) confer species-specificity and reproductive isolation of the sex pheromone blend.

The four treatments placed in the field captured two species of Spodoptera: $S$. frugiperda and $S$. cosmioides. Treatments attracted $S$. frugiperda (Anodev, $\chi^{2}=192.4$; $\mathrm{p}<0.001$ ) and $S$. cosmioides (Anodev, $\chi^{2}=40.75$; $\mathrm{p}<0.001)$ differently. Contrast analysis showed that $S$. frugiperda males were significantly more trapped in the treatment containing its commercial pheromone blend (Biofrugiperda) than in the other treatments (Figure 5). The number of $S$. frugiperda males captured in traps containing the binary blend [Z9-12OAc and Z9,E12-14:OAc (10:1)] was lower, in comparison to the other treatments (Figure 5). Compared to the blank traps, the ones containing two conspecific females $(t=4.23 ; \mathrm{df}=16 ; \mathrm{p}<0.001)$ and those with the binaryblend $(t=3.92 ; \mathrm{df}=16 ; \mathrm{p}=0.001)$ captured more $S$. cosmioides males (Figure 5). The number of $S$. cosmioides males captured in traps containing $S$. frugiperda commercial pheromone was higher than those of the blank traps $(t=2.77 ; \mathrm{df}=16 ; \mathrm{p}=0.01)$, but lower than those captured by the binary blend (Z9-14:OAc and Z9,E12-14:OAc) $(t=2.11 ; \mathrm{df}=16 ; \mathrm{p}=0.05)$.

Field experiment results corroborate those obtained by the wind tunnel bioassays. Spodoptera cosmioides was attracted to the commercial pheromone blend, that contains $Z 7-12$ :OAc, but it was more attracted to the binary solution of Z9-14:OAc and Z9,E12-14OAc, showing that this binary blend might be used for monitoring this species in the field. Laboratory and field results, obtained in the present work, suggest that moths can distinguish the specific blends, but there is some degree of cross-attraction between $S$. frugiperda and $S$. cosmioides pheromone blends. The synthetic mixture of Z9-14:OAc and Z9,E12-14OAc was able to attract both $S$. cosmioides and $S$. frugiperda in field conditions, suggesting the possibility of using a single synthetic mixture to attract more than one species of Spodoptera in field conditions. Cross-attraction between Spodoptera species was also previously demonstrated for $S$. triturata (Walker), S. exempta (Walker) and S. littoralis (Boisduval) (Khasimuddin \& Lubega, 1984), S. eridania and S. exigua (Hübner) (Mitchell \& Tumlinson, 1994), and between native and exotic species in Florida, USA (Meagher et al., 2008). In general, cross-attraction in Spodoptera is related to the major compounds that are shared by species attracted to the same pheromone blend as observed for $S$. cosmioides and S. frugiperda in the present work.

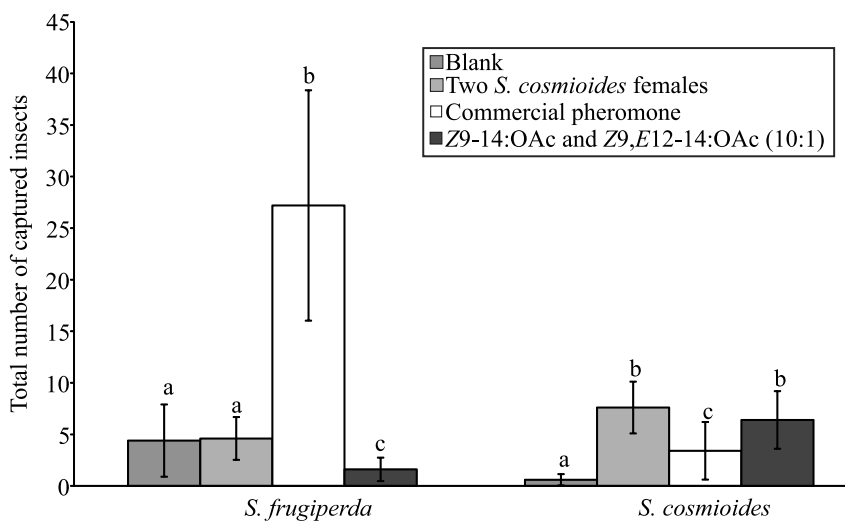

Figure 5. Total number (mean $\pm \mathrm{SD}$ ) of Spodoptera frugiperda and $S$. cosmioides males captured in cotton field experiments using four different treatments: blank, grey rubber septum impregnated with pentane; two twoday-old $S$. cosmioides females; commercial pheromone of $S$. frugiperda (Biofrugiperda), which contained the compounds Z9-12:OAc, Z11-16:OAc, and Z7-12:OAc; and grey rubber septum impregnated with $Z 9-14: O A c$ and $Z 9, E 12-14: O A c$, at 10:1. $\mathrm{N}=5$ traps for each treatment. Bars followed by different letters for each species indicate statistical differences in the proportion of responses between treatments (general linear models, deviance analyses and contrast analyses, $\mathrm{p}<0.05$ ). 
An interesting aspect of this study was that the field experiments showed that it is possible to use just the two major compounds found in the sex pheromone glands of $S$. cosmioides to monitor this species in field crops. Different Spodoptera species coexist at the same time in the field, and to use cheap and efficient pheromone traps that capture more than one species might be very useful for farmers. However, more intensive field work is required, in order to assess the effectiveness of these pheromone traps as monitoring tools, as well as to test the relationships between trap catch and population densities, to define more accurately the precise volatile pheromone blend for these two components, and to evaluate the possibility of capturing more Spodoptera species.

\section{Conclusions}

1. (9Z)-9-Tetradecenyl acetate and (9Z,12E)-9, 12-tetradecadienyl acetate play an important role as pheromone components for conspecific males.

2. (9Z)-9-Tetradecenyl acetate and (9Z,12E)-9, 12-tetradecadienyl acetate are as efficient as females in capturing $S$. cosmioides males in field conditions.

3. The wind tunnel bioassays and field experiment showed that there is pheromonal cross-attraction of $S$. frugiperda and $S$. cosmioides.

4. The response of $S$. frugiperda males is more species-specific than that of $S$. cosmioides.

\section{Acknowledgments}

To Conselho Nacional de Desenvolvimento Científico e Tecnológico (CNPq), and to Fundação de Apoio à Pesquisa do Distrito Federal (FAP-DF), for financial support and fellowship granted; to Isabella Grisi, for helping with rearing of the insects in laboratory; and to Patrick Mayon, for the support in the NMR analysis. Rothamsted Research receives grantaided support from the Biotechnology and Biological Sciences Research Council of the United Kingdom.

\section{References}

ACÍN, P.; ROSEll, G.; GUERRERO, A.; QUERO, C. Sex pheromone of the Spanish population of the beet armyworm Spodoptera exigua. Journal of Chemical Ecology, v.36, p.778-786, 2010. DOI: 10.1007/s10886-010-9817-z.

ANDO, T.; INOMATA, S.-I.; YAMAMOTO, M. Lepidopteran sex pheromones. In: SCHULZ, S. (Ed.). The chemistry of pheromones and other semiochemicals I. Berlin: Springer-Verlag Berlin Heidelberg, 2004. p.51-96. (Topics in Current Chemistry, 239). DOI: $10.1007 / \mathrm{b} 95449$.

BATISTA-PEREIRA, L.G.; STEIN, K.; PAULA, A.F. de; MOREIRA, J.A.; CRUZ, I.; FIGUEIREDO, M. de L.C.; PERRI JR., J.; CORRÊA, A.G. Isolation, identification, synthesis, and field evaluation of the sex pheromone of the Brazilian population of Spodoptera frugiperda. Journal of Chemical Ecology, v.32, p.1085-1099, 2006. DOI: 10.1007/s10886-006-9048-5.

BAVARESCO, A.; GARCIA, M.S.; GRÜTZMACHER A.D.; RINGENBERG, R.; FORESTI, J. Adequação de uma dieta artificial para a criação de Spodoptera cosmioides (Walk.) (Lepidoptera: Noctuidae) em laboratório. Neotropical Entomology, v.33, p.155-161, 2004. DOI: 10.1590/S1519-566X2004000200005.

EL-SAYED, A.M.; DELISLE, J.; DE LURY, N.; GUT, L.J.; JUDD, G.J.R.; LEGRAND, S.; REISSIG, W.H.; ROELOFS, W.L.; UNELIUS, C.R.; TRIMBLE R.M. Geographic variation in pheromone chemistry, antennal electrophysiology, and pheromone-mediated trap catch of North American populations of the obliquebanded leafroller. Environmental Entomology, v.32, p.470-476, 2003. DOI: 10.1603/0046-225X-32.3.470.

ENDO, N.; WADA, T.; NISHIBA, Y.; SASAKI, R. Interspecific pheromone cross-attraction among soybean bugs (Heteroptera): Does Piezodorus hybneri (Pentatomidae) utilize the pheromone of Riptortus clavatus (Alydidae) as a kairomone? Journal of Chemical Ecology, v.32, p.1605-1612. 2006. DOI: 10.1007/ s10886-006-9093-0.

GROOT, A.T.; MARR, M.; SCHÖFL, G.; LORENZ, S.; SVATOS, A.; HECKEL, D.G. Host strain specific sex pheromone variation in Spodoptera frugiperda. Frontiers in Zoology, v.5, p.1-13, 2008. DOI: 10.1186/1742-9994-5-20.

JURENKA, R.A. Insect pheromone biosynthesis. In: SCHULZ, S. (Ed.). The chemistry of pheromones and other semiochemicals I. Berlin: Springer-Verlag Berlin Heidelberg, 2004. p.91-151. (Topics in Current Chemistry, 239). DOI: 10.1007/b95450.

KHASIMUDDIN, S.; LUBEGA, M.C. Quantitative bioassays for sex pheromone analysis in Spodoptera exempta (Wlk.)(Lepidoptera, Noctuidae), and laboratory evidence of cross-attraction among three species. International Journal of Tropical Insect Science, v.5, p.325-328, 1984. DOI: 10.1017/S1742758400001636.

LALANNE-CASSOU, B.; SILVAIN, J.-F.; MONTI, L.; MALOSSE, C. Mecanismes d'isolement reproducteur chez les espèces du complexe néotropical Spodoptera latisfascia - $S$. cosmioides - S. descoinsi (Lepidoptera: Noctuidae). Annales de la Société Entomologique de France, v.35, p.109-116, 1999.

LIMA, A.R. de; LOUREIRO, E. de S.; MUCHALAK, F.; TAIRA, T.L.; FERREIRA, F.N.; NOCCHI, M.J. Ocorrência de Nomuraea rileyi na Spodoptera cosmioides em Chapadão do Sul, MS. Tecnologia and Ciência Agropecuária, v.9, p.57-59, 2015.

MA, T.; LI, Y.; SUN, Z.; WEN, X. (Z,E)-9,12-Tetradecadien-1-ol: a major sex pheromone componente of Euzophera pyriella (Lepidoptera: Pyralididae) in Xinjiang, China. Florida Entomologist, v.97, p.496-503, 2014. DOI: 10.1653/024.097.0221.

MEAGHER, R.L.; BRAMBILA, J.; HUNG, E. Monitoring for exotic Spodoptera species (Lepidoptera: Noctuidae) in 
Florida. Florida Entomologist, v.91, p.517-522. 2008. DOI: 10.1653/0015-4040-91.4.517.

MITCHELL, E.R.; TUMLINSON, J.H. Response of Spodoptera exigua and S. eridania (Lepidoptera: Noctuidae) males to synthetic pheromone and $S$. exigua females. Florida Entomologist, v.77, p.237-247, 1994. DOI: $10.2307 / 3495509$.

MONTI, L.; LALANNE-CASSOU, B.; LUCAS, P.; MALOSSE, C.; SILVAIN, J.-F. Differences in sex pheromone communication systems of closely related species: Spodoptera latifascia (Walker) and $S$. descoinsi Lalanne-Cassou \& Silvain (Lepidoptera: Noctuidae). Journal of Chemical Ecology, v.21, p. 641-660, 1995. DOI: 10.1007/BF02033707.

MOSCARDI, F.; BUENO, A.F.; SOSA-GOMEZ, D.R.; ROGGIA, S.; HOFFMANN-CAMPO, C.B.; POMARI, A.F.; CORSO, I.C.; YANO, S.A. Artrópodes que atacam as folhas de soja. In: HOFFMANN-CAMPO, C.B.; CORRÊA-FERREIRA, B.S.; MOSCARDI, F. (Ed.). Soja: manejo integrado de insetos e outros artrópodes-praga. Brasília: Embrapa, 2012. p.203-334.

NAGOSHI, R.N. Can the amount of corn acreage predict fall armyworm (Lepidoptera: Noctuidae) infestation levels in nearby cotton? Journal of Economic Entomology, v.102, p.210-218, 2009. DOI: 10.1603/029.102.0130.

NATIONAL INSTITUTE OF STANDARDS AND TECHNOLOGY. NIST/EPA/NIH Mass Spectral Library (NIST 08) and NIST Mass Spectral Search Program (Version 2.0f) for use with Microsoft Windows: user's guide. Gaithersburg: NIST, 2008. Disponível em: < http://www.nist.gov/srd/upload/Ver20Man. pdf $>$. Acesso em: 10 fev. 2016.

POMARI, A.F.; BUENO, A.F.; BUENO, R.C.O.F.; MENEZES JR., A.O. Telenomus remus Nixon egg parasitization of three species of Spodoptera under different temperatures. Neotropical Entomology, v.42, p.399-406, 2013. DOI: 10.1007/ s13744-013-0138-0.

R DEVELOPMENT CORE TEAM. R: a language and environment for statistical computing. Vienna: R Foundation for Statistical Computing, 2007. Disponível em: <http://www.r-project.org/>. Acesso em: 10 fev. 2016.

SAVEER, A.M.; BECHER, P.G.; BIRGERSSON, G.; HANSSON, B.S.; WITZGALL, P.; BENGTSSON, M. Mate recognition and reproductive isolation in the sibling species Spodoptera littoralis and Spodoptera litura. Frontiers in Ecology and Evolution, v.2, p.1-6, 2014. DOI: 10.3389/ fevo.2014.00018.

SCHMIDT, F.G.V.; MONNERAT, R.G.; BORGES, M.; CARVALHO, R. da S. Metodologia de criação de insetos para avaliação de agentes entomapatogênicos. Brasília: Embrapa Recursos Genéticos e Biotecnologia, 2001. (Embrapa Recursos Genéticos e Biotecnologia. Circular técnica, 11).

SILVAIN, J.-F; LALANNE-CASSOU, B. Distinction entre Spodoptera latifascia (Walker) et Spodoptera cosmioides (Walker), bona species (Lepidoptera, Noctuidae). Revue Francaise d'Entomologie, v.19, p.95-97, 1997.

TEODORO, A.V.; PROCÓPIO, S. de O.; BUENO, A. de F.; NEGRISOLI JUNIOR, A.S.; CARVALHO, H.W.L. de; NEGRISOLI, C.R. de C.B.; BRITO, L.F.; GUZZO, E.C. Spodoptera cosmioides (Walker) e Spodoptera eridania (Cramer) (Lepidoptera: Noctuidae): novas pragas de cultivos da região Nordeste. Aracaju: Embrapa Tabuleiros Costeiros, 2013. (Embrapa Tabuleiros Costeiros. Comunicado técnico, 131).

TEIXEIRA, A.L.; DE OLIVEIRA, J.S.; VILELA, E.F.; DE LIMA, E.R.; REIS, H.O. Sex pheromone components of Spodoptera latifascia Walker (Lepidoptera: Noctuidae). Revista Ceres, v.36, p.373-381, 1989.

TILLMAN, P.G.; ALDRICH, J.R.; KHRIMIAN, A.; COTTRELL, T.E. Pheromone attraction and cross-attraction of Nezara, Acrosternum, and Euschistus spp. stink bugs (Heteroptera: Pentatomidae) in the field. Environmental Entomology, v.39, p.610-617, 2010. DOI: 10.1603/EN09114.

UJVÁRY, I.; KIS-TAMÁS, A.; NOVÁK, L. Simple and economic syntheses of some (Z)-7- and (Z)-9-alkenyl acetates, and of $(E, Z)$-7,9-dodecadien-1-yl acetate, the sex pheromone of the European grapevine moth, using aleuritic acid as a common starting material. Journal of Chemical Ecology, v.11, p.113-124, 1985. DOI: $10.1007 / \mathrm{BF} 00987610$.

UNBEHEND, M.; HÄNNIGER, S.; MEAGHER, R.L.; HECKEL, D.G.; GROOT, A.T. Pheromonal divergence between two strains of Spodoptera frugiperda. Journal of Chemical Ecology, v.39, p.364-376, 2013. DOI: 10.1007/s10886-013-0263-6.

Received on June 24, 2015 and accepted on February 12, 2016 